\title{
Antioxidant, Antibacterial and Anti-Clastogenic Activities of Lunasia amara, Blanco Leaf Extract
}

\author{
Ivan Darwin V. Totaan ${ }^{1}$, Zenaida D. Calma ${ }^{1}$, Michael Angelo C. Nicdao ${ }^{2}$ \\ and Evelyn V. Totaan ${ }^{2}$ \\ ${ }^{1}$ Angeles City Science High School, Angeles City, Philippines \\ ${ }^{2}$ College of Arts and Sciences, Pampanga State Agricultural University, \\ Magalang, Pampanga, Philippines
}

\section{ABSTRACT}

The study evaluated the antioxidant, antibacterial and anti-clastogenic activities of the leaf extract of Lunasia amara, Blanco. DPPH Free Radical Scavenging Assay revealed that the leaf extract (at $6 \mathrm{mg} / \mathrm{mL}$ concentration) possesses the potential to cause free-radical scavenging/ antioxidant activity. Modified Resazurin-96-well based assay showed that the leaf extract possesses the potential to cause significant inhibition on the growth of Staphylococcus aureus, ATCC 25923) and Escherichia coli ATCC 25922 at $6 \mathrm{mg} / \mathrm{mL}-100 \mathrm{mg} / \mathrm{L}$ concentrations. Micronucleus test revealed that the leaf extract (at $20 \mathrm{mg} / \mathrm{mL}$ and $200 \mathrm{mg} / \mathrm{mL}$ concentrations), did not cause chromosome-breakage on white mice, however, possesses the ability to reduce the chromosome breakage of Mitomycin $\mathrm{C}$ on white mice, hence, anti-clastogenic. Result of the study can help different agencies in the discovery of potential medicinal values of different plants, particularly the indigenous plants in the Philippines. It can provide cheaper nature-based alternative medicine to the public in the midst of high-priced medicine produced by pharmaceutical companies. Through this study, the importance of plant biodiversity in Mt. Arayat, Pampanga, Philippines will also be highlighted as a source of raw materials (i.e., plants) medicinal purposes.

Key words: Antioxidant, antibacterial, anti-clastogenic, Lunasia amara,Blanco

Corresponding Author: Evelyn V. Totaan, evtotaan@gmail.com

\section{INTRODUCTION}

Organisms, specifically humans, are susceptible to many diseases. Every day, new drugs are being manufactured to cure these diseases. However, these drugs have certain side effects that can cause more potential harm than good. Hence, medicines that are plant-based and natural must be discovered and manufactured to optimize the healing they can bring and minimize, or even eliminate the harm they can cause to humans.

Over the past centuries, plants have been used for treating illnesses and injuries. These medicinal plants which can be found everywhere, are herbs, vines, shrubs or trees, from which medicine can be extracted from the roots, wood, bark, leaves, seeds, flower or fruit to heal specific illnesses and diseases. These medicinal plants are very popular in the rural areas and knowledge of their healing powers is passed on from one generation to another. 
According to the World Health Organization survey, 70-80\% of the world population depends on herbal sources as primary health care needs and medicinal plants are the best source in obtaining a variety of drugs. Plant derived compounds (phytochemicals) have been attracting much interest as natural alternatives to synthetic compounds. Extracts of plants were used for the treatment of various diseases. Studies have found out that the medicinal properties of plants may be accounted to the secondary metabolites they contain [1]. Plants represent a vast source of natural antioxidants, antibiotics and antimutagenics.

Before a plant or a preparation made from plants can be administered to human subjects, the plant is subjected to pharmaceutical, chemical and toxicological studies in experimental animals. Therefore, such plants should be investigated for better understanding of their properties, safety and efficacy.

One particular plant of interest is the Lunasia amara Blanco, an indigenous plant found in Mt. Arayat Pampanga, Philippines. This is a plant which is being used by the Aeta Community in Cananaoan, Arayat, Pampanga in treating digestive disorders, swollen limbs, skin diseases and as remedy for snakebite. Such uses are supported by Macabeo, et al. [2] in his study.

Phytochemical analysis revealed that quinoline alkaloid lunacridine is the active component responsible for the medicinal uses of L. amara [3], Further, in the study of Rojales and Totaan [4], it was also found to contain flavonoids and steroids, also of medicinal importance.

Many of the estimated 12,000 known alkaloids have been exploited as pharmaceuticals, stimulants, narcotics and poisons due to their active and potent biological activities [5]. Many of them are toxic. Alkaloids' toxicity serves as a weapon to inhibit the action of predators, like herbivores [6]. Still, a lot of alkaloids are related with a wide range of pharmacological activities. Alkaloids have strong anti-bacterial and anti-cancer biological activities and are widely used as a compound of drugs and herbal therapy formulation [7].

Flavonoids, on the other hand, have gained considerable interest due to their potential benefits to human health including anti-inflammatory, antioxidant, anti-viral, anti-allergic, anti-hepatotoxic, anti-ulcer, anti-carcinogenic and antitumor activities $([8,9]$

Steroids have great diversity of physiological activities which include the development and control of the reproductive tract of humans. Steroids also have a great spectrum of pharmacological applications such as orgeosterol, which is a vitamin D precursor [10], which can shield the interaction of mutagens with base pairs of DNA [11].

Thus, this study would aimed to find out the therapeutic ability of L. amara, with an end goal of providing cheaper nature-based alternative medicine to the public in the midst of high-priced medicine produced by pharmaceutical companies. Through this study, the importance of plant biodiversity in Mt. Arayat, Pampanga, Philippines will also be highlighted as a source of raw materials (i.e., plants) for medicinal purposes.

Specifically, this study sought to find out the free-radical scavenging/anti-oxidant activity of Lunasia amara Blanco, its ability to inhibit the growth of Staphylococcus aureus, ATCC 25923 (Gram positive) and Escherichia coli, ATCC 25922 (Gram negative bacteria) and its chromosomebreaking potential (clastogenic) and the ability to reduce the chromosome-breaking activity of Mitomycin C on the bone marrow cells of white mice (Mus musculus, L). 


\section{MATERIALS AND METHODS}

Plant Collection and Identification. Lunasia amara leaves were collected in the northwestern slope of Mt. Arayat, Pampanga, Philippines. The plant samples were identified and authenticated by a taxonomist from the National Museum. Data collection was done in accordance with the institutional, national, and international principles and guidelines of plant use and conservation of biodiversity. The leaves of the plants were washed thoroughly with distilled water and air-dried for 24 to 48 hours at room temperature.

Preparation of Plant Extract. Two-hundred fifty grams of the air-dried leaves of L. amara, cut to a coarse powder, were placed in an amber bottle with $500 \mathrm{~mL}$ of $95 \%$ ethanol to submerge the material. The leaves were soaked for 24 to 48, filtered through a Whatmann filter paper and concentrated in vacuo $\left(40^{\circ} \mathrm{C}\right)$ to $1 / 10^{\text {th }}$ the original volume using a rotary evaporator. Extracts were dried overnight in an oven at $37 \pm 2^{\circ} \mathrm{C}$, stored in a tightly stoppered amber bottle in the refrigerator at $4{ }^{\circ} \mathrm{C}$, properly labelled, with the name of plant, concentration (in $\mathrm{g} / \mathrm{mL}$ ) and date of extraction.

Anti-oxidant Screening (DPPH Free Radical Scavenging Assay) [12]. The following were the different treatments, with three trials in triplicate per treatment.

T+ - Positive control (Gallic Acid)

$\mathrm{T} 1-$ L. amara leaf extract, $6 \mathrm{mg} / \mathrm{mL}$

T- - Negative control (DMSO)

A $300 \mu \mathrm{M}$ free-radical solution was prepared by dissolving $1 \mathrm{mg}$ of 2,2-diphenyl-1-(2,4,6trinitrophenyl)hydrazyl (DPPH) in $10 \mathrm{~mL}$ absolute ethanol. The solution at $95 \mu \mathrm{L}$ was dispensed to 96-well microtiter plates using multi-channel pippettor. Gallic acid was used as positive control while DMSO, the solvent of the sample, was used as negative control. Five microliters of the controls and plant extracts with $6 \mathrm{mg} / \mathrm{mL}$ concentration were added to the wells to make a final volume of $100 \mu \mathrm{L}$. The plate was incubated in dark and ambient temperature for 60 minutes. After incubation, absorbance was read at $520 \mathrm{~nm}$ using UV spectrophotometer. Based on the absorbance readings, free radical inhibition of the test sample was computed using the formula:

$$
\% \text { inhibition }=\frac{(\text { Absorbance }(-) \text { control }- \text { Absorbance sample })}{(\text { Absorbance }(-) \text { control }- \text { Absorbance gallic acid })} \times 100
$$

Antibacterial Test (Modified Risazurin-96-well based assay [13]. The following were the different treatments (2x dilution) with three replicates per treatment, given to Gram positive (Staphylococcus aureus, ATCC 25923) and Gram negative (Escherichia coli, ATCC 25922) bacteria.

$$
\begin{aligned}
& \text { T+ - Positive control (Amoxicillin) } \\
& \text { T1 }-\sim 100 \mathrm{mg} / \mathrm{mL} \text { L. amara leaf extract } \\
& \text { T2 }-\sim 50 \mathrm{mg} / \mathrm{mL} \text { L. amara leaf extract } \\
& \text { T3 }-\sim 25 \mathrm{mg} / \mathrm{mL} \text { L. amara leaf extract } \\
& \text { T4- } 12 \mathrm{mg} / \mathrm{mL} \text { L. amara leaf extract } \\
& \text { T5 }-\sim 6 \mathrm{mg} / \mathrm{mL} \text { L. amara leaf extract } \\
& \text { T6- } \sim 3 \mathrm{mg} / \mathrm{mL} \text { L. amara leaf extract } \\
& \text { T7- } 1.5 \mathrm{mg} / \mathrm{mL} \text { L. amara leaf extract } \\
& \text { T8- } 0.75 \mathrm{mg} / \mathrm{mL} \text { L. amara leaf extract } \\
& \text { T9- } 0.38 \mathrm{mg} / \mathrm{mL} \text { L. amara leaf extract } \\
& \text { T10- } \sim 0.19 \mathrm{mg} / \mathrm{mL} \text { L. amara leaf extract }
\end{aligned}
$$




\section{T - - Negative control (DMSO / Sterile distilled Water)}

Sterile 96-well plates for the antibacterial assay were prepared in a Biosafety Cabinet Level II. One hundred fifty microliters $(150 \mu \mathrm{L})$ of Mueller-Hinton Broth (MHB) was added to Wells 1 to 10 (columns $\mathrm{A}$ to $\mathrm{H}$ ) of the 96-wells microtiter plates using a multichannel pipettor, followed by 150 $\mu \mathrm{L}$ of the $200 \mu \mathrm{g} / \mathrm{mL}$ extract to Wells 1 of columns A to C, $150 \mu \mathrm{L}$ of the $100 \mu \mathrm{g} / \mathrm{mL}$ Amoxicillin (D to F), $150 \mu \mathrm{L}$ DMSO (G) and $150 \mu \mathrm{L}$ sterile distilled Water (H). Two-fold serial dilutions (in descending concentrations) were performed starting from Well 1 until Well 10. One hundred fifty microliters of the mixture from Well 1 was transferred to Well 2 and mixed by pipetting. This was repeated to Well 2 until Well 10. Finally, $150 \mu \mathrm{L}$ bacterial suspension $\left(2.0 \times 10^{6} \mathrm{cfu} / \mathrm{mL}\right.$ was added to the wells and were incubated for 18 hours at $35 \pm 2{ }^{\circ} \mathrm{C}$. The final concentration was $1.0 \times 10^{6}$ $\mathrm{cfu} / \mathrm{mL}$. There were two 96-well microtiter plates prepared; one with Gram positive bacteria ( $S$. aureus, ATCC 25923) and another with Gram negative bacteria (E. coli, ATCC 25922).

After 18 hours of incubation, growth turbitidy of each well was noted and $30 \mu \mathrm{L}$ resazurin was added to each well and incubated for another 6 hours. In the presence of bacterial growth, the blue resazurin is metabolically converted to a pink resorufin. The color change was assessed visually. Any color change to pink or colorless was recorded as positive to bacterial growth. The lowest concentration at which color change occurred was taken as the Minimum Inhibitory Concentration or MIC. The average of the three values was calculated and served as the MIC for the test material and bacterial strain.

Clastogenic and Anti-clastogenic Screening (Micronucleus Test [14]). The following treatments were used with three replications per treatment, with one Balb-C mice (aged seven to twelve weeks old, weighing approximately 15 to 25 grams) per replicate.

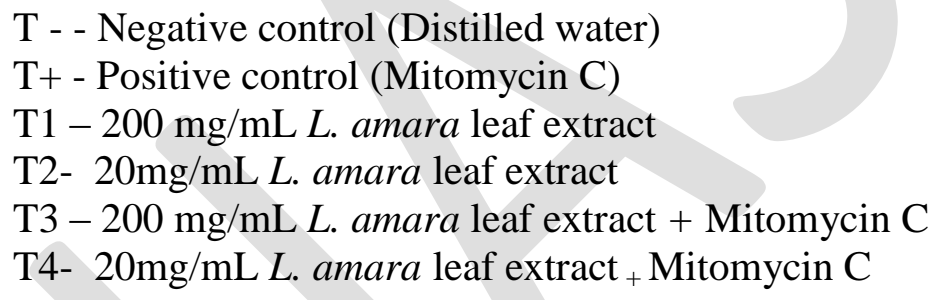

The mice were placed separately in a $21 \mathrm{~cm} \times 12 \mathrm{~cm}$ plastic cage and were given one week adjustment period to acclimatize them to the laboratory environment. They were fed with commercial creep pellets and distilled water ad libitum. An Institutional Animal Care and Use Committee (IACUC) permit from Pampanga State Agricultural University was secured prior to the conduct of the study.

A dose of $0.5 \mathrm{ml}$ plant extract per 20-gram body weight was introduced to the mice through gavage method. Mitomycin C (positive control) was given intraperitoneally. For the antichromosome breaking/clastogenecity test, $0.0125 \mathrm{ml}$ of Mitomycin $\mathrm{C}$ solution per gram body weight of mice was introduced first, followed immediately by the oral administration of the leaf extracts. The first treatment was administered twenty-four hours before the second treatment. Six hours after the last treatment, the mice were sacrificed through cervical dislocation.

Immediately after sacrificing the mice, both femora were removed by cutting through the pelvis and tibia. The bone was freed from the muscle with the use of the gauze and scalpel blade. The proximal end of the femora was carefully shortened with scissors until a small opening in the bone marrow became visible. 
Then, $0.5 \mathrm{ml}$ fetal/bovine calf serum was sucked into a $1 \mathrm{~mL}$ syringe with a needle, which was inserted into the proximal part of the bone. Fetal calf serum helps preserve the perfect morphology of erythrocytes as well as the nucleated cells. The femur was then submerged in the serum and squeezed against the wall to prevent slipping of the needle. By gentle flushing, the marrow was forced out through the opening around the needle. Suspension was centrifuged at $1000 \mathrm{rpm}$ for five minutes to sediment the cells and supernatant was removed. Cells in the sediment were gently mixed with a Pasteur pipette/micropipette.

A small drop of the viscous suspension was placed at one end of a microscope slide and smeared according to the conventional hematological method. Two slides per mouse were prepared and airdried for at least 24 hours.

Staining of slides was performed a day after their preparation to have good staining quality. Slides were stained with undiluted May-Gruenwald solution for three minutes, then transferred in a diluted 50\% May-Gruenwald solution for two minutes. Slides were washed with distilled water before and after staining for 10 minutes with $15 \%$ Aqueous Giemsa stain solution and blotted dry with a tissue paper before air drying.

The stained slides were screened at a medium magnification for a region of a suitable technical quality. The stain of mature erythrocytes must be red in color and strong bluish tint in the young polychromatic erythrocytes. Using a hand tally counter, one thousand cells per slide were counted using the conventional method giving a total of two thousand cells per mice. Polychromatic cells exhibiting micronucleus were scored. The number of Micronucleated Polychromatic Erythrocytes (MPCEs) in the two slides per mouse were averaged and resulting figures were recorded as the score of the mice.

As a rule, to be considered chromosome-breaking/ clastogenic, the number of MPCEs produced by the test sample must be twice or more than twice the negative control (distilled water). To be considered anti-chromosome breaking/ clastogenic, the number of MPCEs produced by the test sample in combination with Mitomycin $\mathrm{C}$ must be significantly lower when compared with Mitomycin C alone.

All data gathered were subjected to analysis of variance (ANOVA) and Tukey's Multiple Range Test of the Graphpad Prism 7.

\section{RESULTS AND DISCUSSION}

\section{Anti-oxidant/free-radical scavenging activity of Lunasia amara, Blanco}

The antioxidant/free-radical scavenging activity of $6 \mathrm{mg} / \mathrm{ml} \mathrm{L}$. amara was measured using the DPPH free-radical scavenging assay [12]. DPPH is a stable free radical with an absorbance band at $517 \mathrm{~nm}$, which disappears upon reduction (either by accepting an electron or hydrogen radical) by an antiradical compound $[15,16]$. The DPPH method is based on scavenging of the DPPH from the antioxidants which causes fading of DPPH purple color and subsequently, decrease in absorbance [17, 18]. Low absorbance readings correspond to high amount of scavenged free radicals by the antioxidants, in this case, Gallic acid (Fig. 1). Antioxidants are substances when present at low concentrations compared with those of the oxidizable substrate, considerably delay or inhibit oxidation of the substrate [19]. 


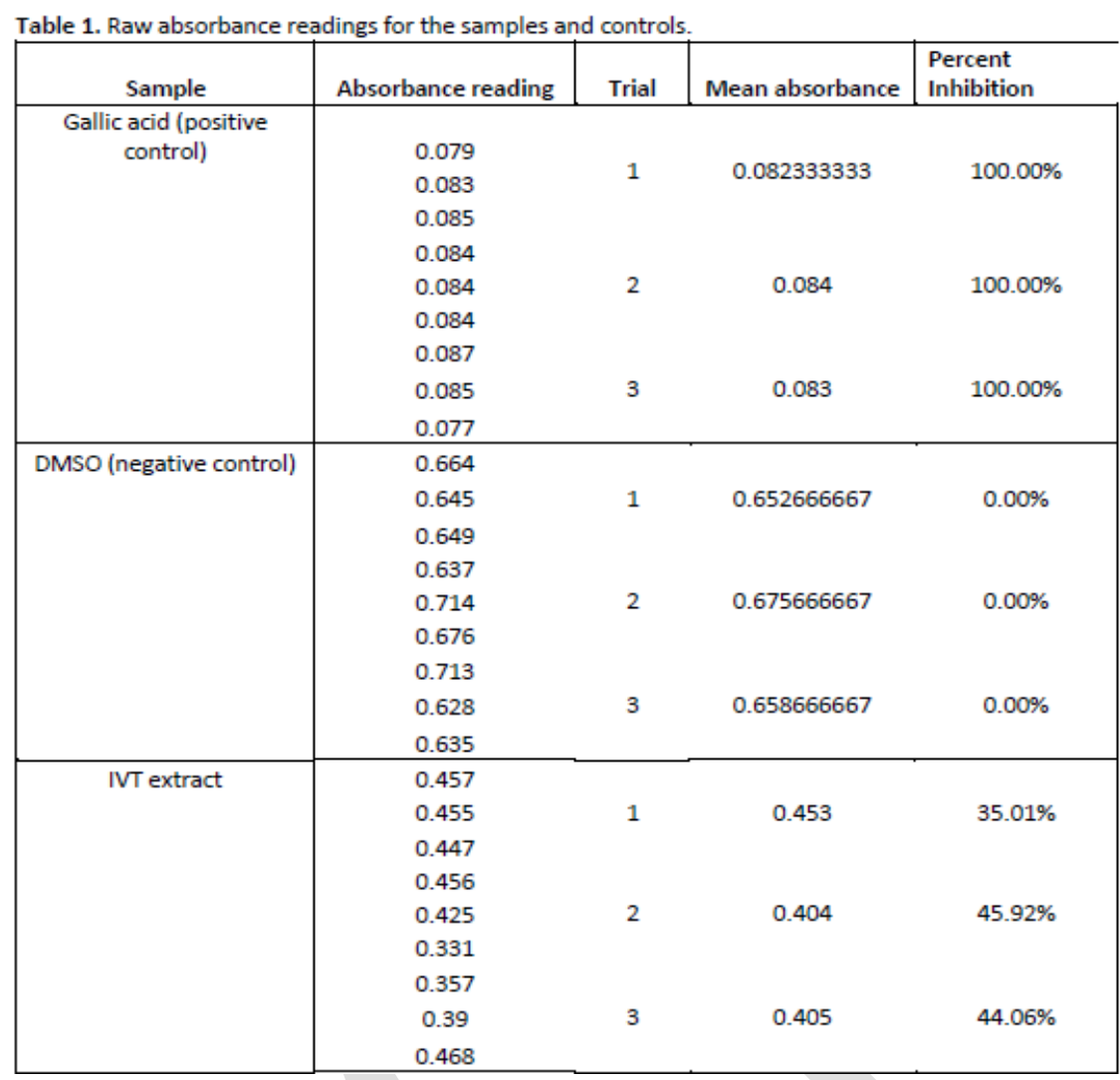

Fig. 1. Raw absorbance readings for L. amara leaf extract (IVT) extract and controls

Fig. 2 shows that the scavenging activity of the L. amara leaf extract is significantly lower compared to gallic acid, but significantly higher than DMSO. Gallic acid registered the highest percent (\%) inhibition, followed by the leaf extract, while no inhibition was observed in DMSO. Statistical analysis using the analysis of variance (ANOVA) revealed that the data means are significantly different among each other at $5 \%$ level, with p-value of $<0.0001$

Gallic acid (GA) (3,4,5-trihydroxybenzoic acid), a naturally occurring low molecular weight triphenolic compound, has been suggested to possess strong antioxidant activities in many studies, having reduced 6 DPPH radicals per molecule. It was demonstrated that GA adopt a hydrogen donating mechanism to scavenge the DPPH radical. It provides efficient protection against oxidative damage caused by reactive species often encountered in biological systems including, hydroxyl $(\mathrm{HO} \bullet)$, superoxide $(\mathrm{O} 2 \bullet-)$, and peroxyl $(\mathrm{ROO} \bullet)$ and the non-radicals, hydrogen peroxide $(\mathrm{H} 2 \mathrm{O} 2)$ and hypochlorous acid $(\mathrm{HOCl})$. Furthermore, GA has been demonstrated as the chief antioxidant component responsible for the efficient antiradical and anticancer properties of a number of plant extracts [16].

The leaf extract has also been found to have scavenging activity as shown on the percent inhibition, which is $41.66 \pm 5.84 \%$, though it does not register the same scavenging activity with that of gallic acid. The observed antioxidant activity may be due to the presence of any of phenolic compounds present in the plant, specifically flavonoids [3]. The antioxidant activity of flavonoids is due to their ability to reduce free radical formation and to scavenge free radicals [20,21].

Dimethyl sulfoxide (DMSO), which served as negative control, on the other hand, showed no scavenging activity as reflected by the absence of inhibition $(0 \%)$. 


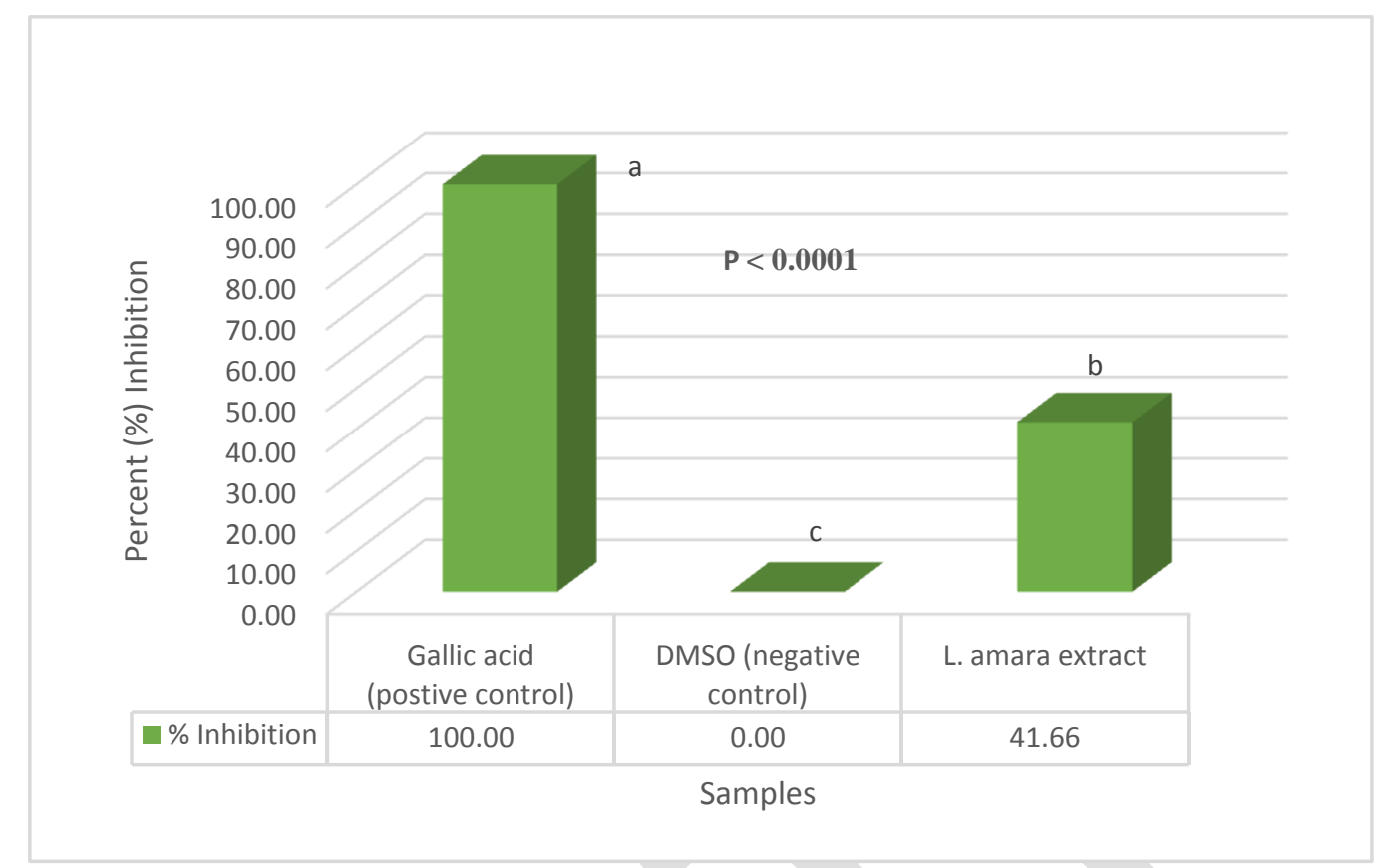

*Means of the same letter are not significantly different at $5 \%$ level

Fig. 2. Antioxidant/free-radical scavenging activity of $L$. amara leaf extract

Antibacterial Activity of Lunasia amara, Blanco against Staphylococcus aureus, ATCC 25923 and Escherichia coli, ATCC 25922

Antibacterial screening of L. amara against the wild-type strains of S. aureus ATCC 25923 and $E$. coli (ATCC 25922) was done using the Modified Resazurin-96-well based assay. Resazurin is an oxidation-reduction indicator used for the evaluation of cell growth, particularly in various cytotoxicity assays. It is a blue non-fluorescent and non-toxic dye that becomes pink and fluorescent when reduced to resorufin by oxidoreductases within viable cells. Resorurfin is further reduced to hydroresorufin (uncoloured and nonfluorescent) [13].

Fig. 3 shows the growth turbidity of E. coli ATCC 25922 after 18 hours of incubation with twofold serially diluted plant extract (rows A,B,C), two-fold serially diluted Amoxicillin (rows D,E,F) and solvents (rows $\mathrm{G}, \mathrm{H}$ ). Plant extract concentrations are $\approx 100 \mathrm{mg} / \mathrm{mL}(1), \approx 50 \mathrm{mg} / \mathrm{mL}(2), \approx 25$ $\mathrm{mg} / \mathrm{mL}(3), \approx 12 \mathrm{mg} / \mathrm{mL}(4), \approx 6 \mathrm{mg} / \mathrm{mL}(5), \approx 3 \mathrm{mg} / \mathrm{mL}(6), \approx 1.5 \mathrm{mg} / \mathrm{mL}$ (7), $\approx 0.75 \mathrm{mg} / \mathrm{mL}(8)$, $\approx 0.38 \mathrm{mg} / \mathrm{mL}(9)$ and $\approx 0.19 \mathrm{mg} / \mathrm{mL}(10)$. Antibiotic concentrations are $\approx 500 \mu \mathrm{g} / \mathrm{mL}(1), \approx 250 \mu \mathrm{g}$ $/ \mathrm{mL}(2), \approx 125 \mu \mathrm{g} / \mathrm{mL}(3), \approx 62 \mu \mathrm{g} / \mathrm{mL}(4), \approx 31 \mu \mathrm{g} / \mathrm{mL}(5), \approx 15 \mu \mathrm{g} / \mathrm{mL}(6), \approx 7.5 \mu \mathrm{g} / \mathrm{mL}(7), \approx 3.8$ $\mu \mathrm{g} / \mathrm{mL}(8), \approx 1.9 \mu \mathrm{g} / \mathrm{mL}(9)$ and $\approx 0.95 \mu \mathrm{g} / \mathrm{mL}(10)$.

Visual observation of turbidity suggests that plant extract inhibited bacterial growth in Wells 1 to 5 of Rows A,B, and C while antibiotic inhibited bacterial growth in Wells 1 to 7 of Rows D,E, and F. Solvents in Rows $\mathrm{G}$ and $\mathrm{H}$ did not inhibit the growth of bacteria in all wells except for Wells 11 and 12 which served as uninoculated controls containing sterile Mueller-Hinton Broth. 


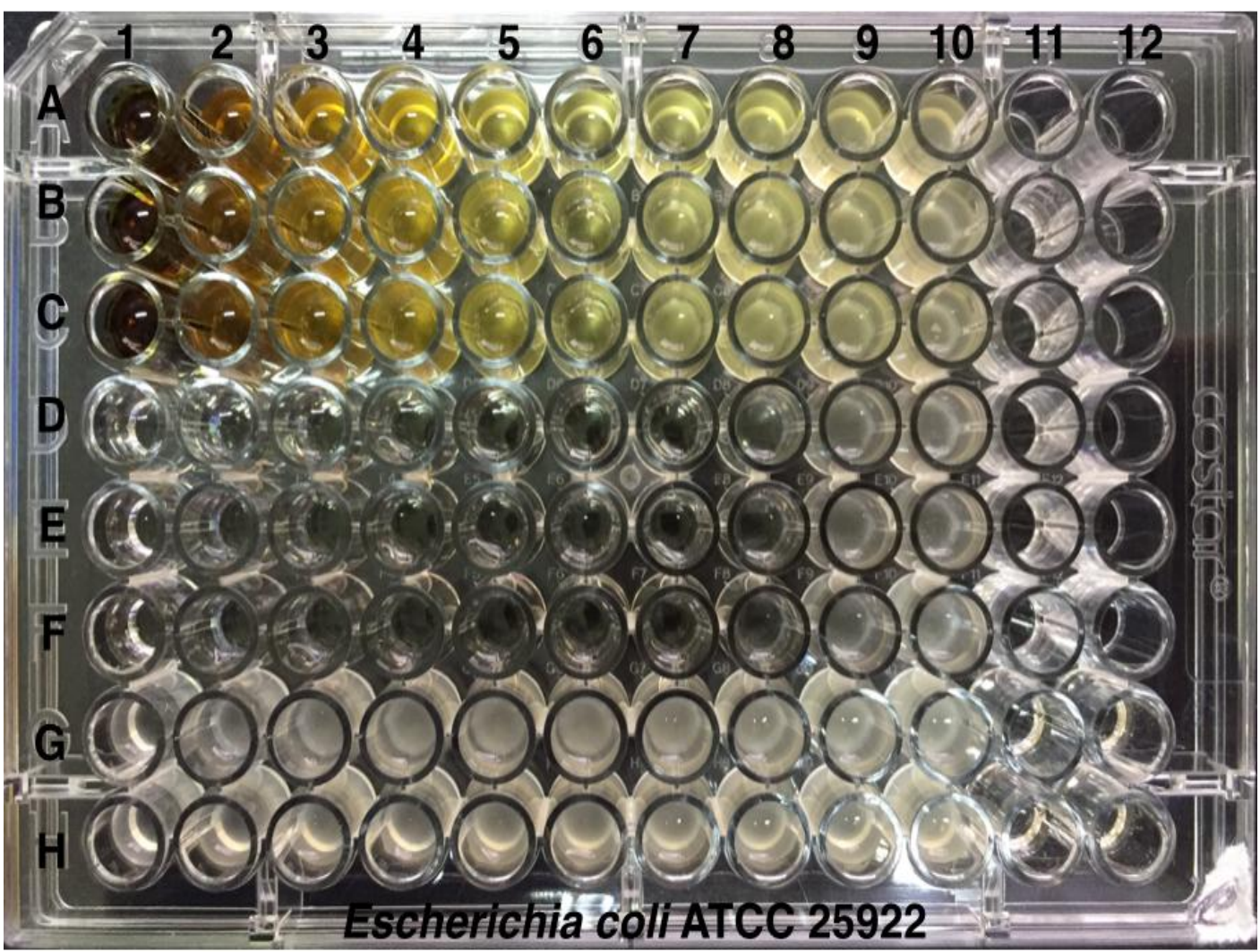

Fig. 3. Growth turbidity of E. coli ATCC 25922 after 18 hours of incubation with two-fold serially diluted plant extract (Rows A,B,C), two-fold serially diluted Amoxicillin (Rows D,E,F) and solvent (Rows G,H).

Fig. 4 shows the viable cells of E. coli ATCC 25922 treated with plant extract and amoxicillin after 18 hours of incubation with resazurin added to each well and incubated for another six hours. The blue resazurin was metabolically converted by live cells to a pink resorufin.

Plant extract concentrations from $\approx 100 \mathrm{mg} / \mathrm{mL}$ to $\approx 6 \mathrm{mg} / \mathrm{mL}$ (wells 1 to 5 of Rows $\mathrm{A}, \mathrm{B}, \mathrm{C}$ ) inhibited the growth E. coli ATCC 25922; viable cells are absent as indicated by the maintenance of the blue color of reazurin. On the other hand, lower concentrations of plant extract did not inhibit the growth; the presence of viable cells converted resazurin to pink resorufin (Wells 6 to 10 of Rows A,B,C).

Amoxicillin (Rows D,E,F) concentrations from $\approx 500 \mu \mathrm{g} / \mathrm{mL}$ to $\approx 7.5 \mu \mathrm{g} / \mathrm{mL}$ (Wells 1 to 7 ) also inhibited bacterial growth. A minimum inhibitory concentration (MIC) of less $8 \mu \mathrm{g} / \mathrm{mL}$ for amoxicillin against $E$. coli ATCC 25922 should be observed to confirm the validity of the assay (CLSI, 2016). The MIC of amoxicillin in this experiment is $\approx 7.5 \mu \mathrm{g} / \mathrm{mL}$, this indicates the accuracy of the results of the experiment especially of the plant extracts.

Bacteria with solvents in Rows $\mathrm{G}$ and $\mathrm{H}$ converted resazurin to a pink resorufin suggesting the presence of viable cells but not in Wells 11 and 12 which contain no viable cells in the sterile Mueller-Hinton Broth. 


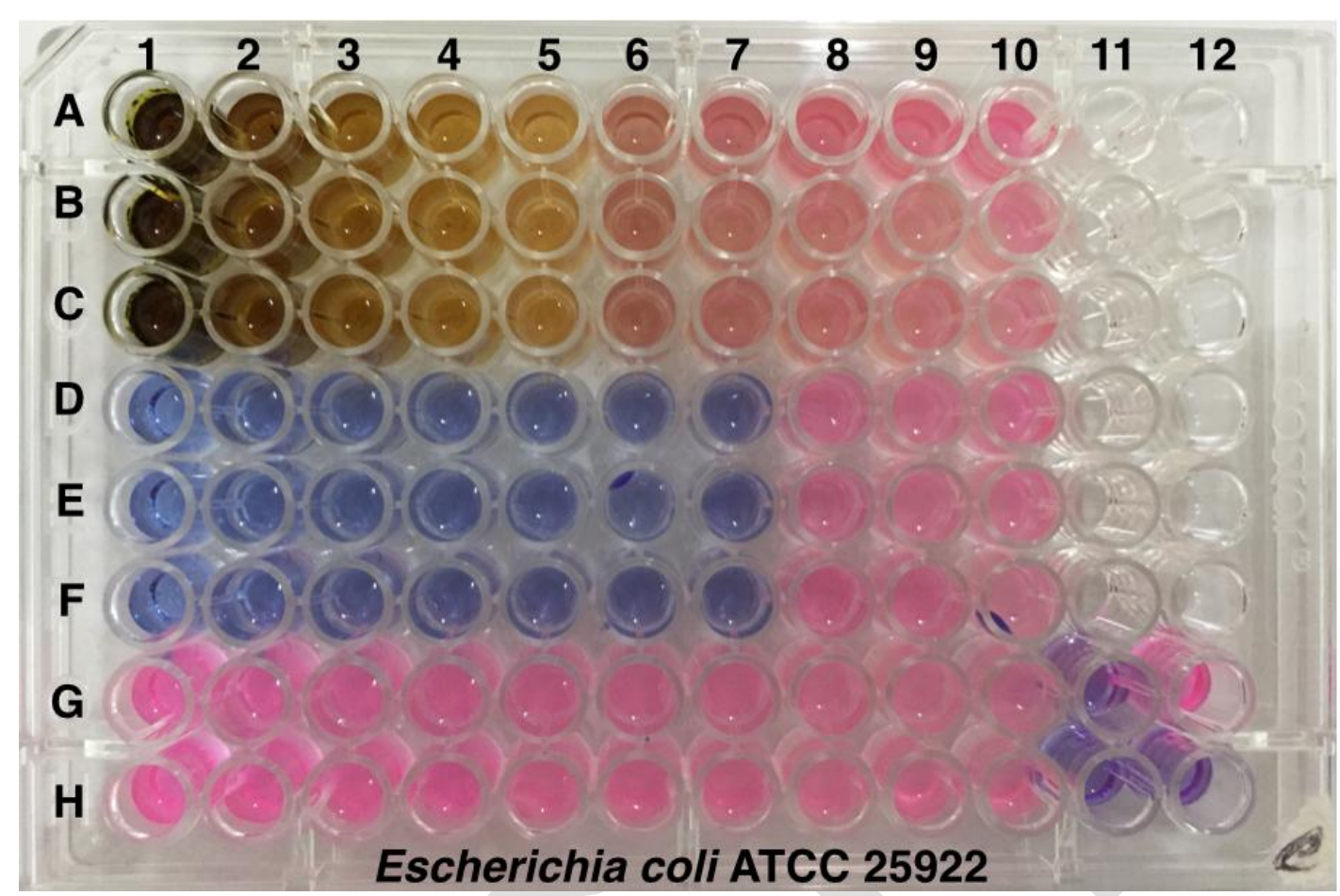

Fig. 4. Viable cells of E. coli ATCC 25922 treated with plant extract and amoxicillin after 18 hours of incubation, with resazurin added to each well and incubated for another 6 hours

Fig. 5 shows the growth turbidity of S. aureus ATCC 25923 after 18 hours of incubation with twofold serially diluted plant extract (Rows A,B,C), two-fold serially diluted Amoxicillin (Rows D,E,F) and solvent (Rows G,H). Plant extract concentrations are $\approx 100 \mathrm{mg} / \mathrm{mL}(1), \approx 50 \mathrm{mg} / \mathrm{mL}$ (2), $\approx 25 \mathrm{mg} / \mathrm{mL}(3), \approx 12 \mathrm{mg} / \mathrm{mL}(4), \approx 6 \mathrm{mg} / \mathrm{mL}(5), \approx 3 \mathrm{mg} / \mathrm{mL}(6), \approx 1.5 \mathrm{mg} / \mathrm{mL}$ (7), $\approx 0.75 \mathrm{mg} / \mathrm{mL}$ (8), $\approx 0.38 \mathrm{mg} / \mathrm{mL}(9)$ and $\approx 0.19 \mathrm{mg} / \mathrm{mL}(10)$. Antibiotic concentrations are $\approx 500 \mu \mathrm{g} / \mathrm{mL}(1), \approx 250 \mu \mathrm{g}$ $/ \mathrm{mL}(2), \approx 125 \mu \mathrm{g} / \mathrm{mL}(3), \approx 62 \mu \mathrm{g} / \mathrm{mL}(4), \approx 31 \mu \mathrm{g} / \mathrm{mL}(5), \approx 15 \mu \mathrm{g} / \mathrm{mL}(6), \approx 7.5 \mu \mathrm{g} / \mathrm{mL}(7), \approx 3.8$ $\mu \mathrm{g} / \mathrm{mL}(8), \approx 1.9 \mu \mathrm{g} / \mathrm{mL}(9)$ and $\approx 0.95 \mu \mathrm{g} / \mathrm{mL}(10)$.

Visual observation of turbidity suggests plant extract inhibited bacterial growth in Wells 1 to 5 of Rows A,B, and C while antibiotic inhibited bacterial growth in Wells 1 to 8 of Rows D,E, and F. Solvents in Rows $\mathrm{G}$ and $\mathrm{H}$ did not inhibit the growth of bacteria in all wells except for wells 11 and 12 which served as uninoculated controls containing sterile Mueller-Hinton Broth.

Fig. 6 shows the viable cells of S. aureus ATCC 25923 treated with plant extract and amoxicillin after 18 hours of incubation. Resazurin was added to each well and incubated for another six hours to detect the viable cells. The blue resazurin is metabolically converted by live cells to a pink resorufin.

Plant extract concentrations from $\approx 100 \mathrm{mg} / \mathrm{mL}$ to $\approx 6 \mathrm{mg} / \mathrm{mL}$ (Wells 1 to 5 of Rows $\mathrm{A}, \mathrm{B}, \mathrm{C}$ ) inhibited the growth of $S$. aureus ATCC 25923 as indicated by a blue color. Lower concentrations of plant extract did not inhibit the growth; viable cells converted resazurin to pink resorufin (Wells 6 to 10 of Rows $A, B, C)$. 


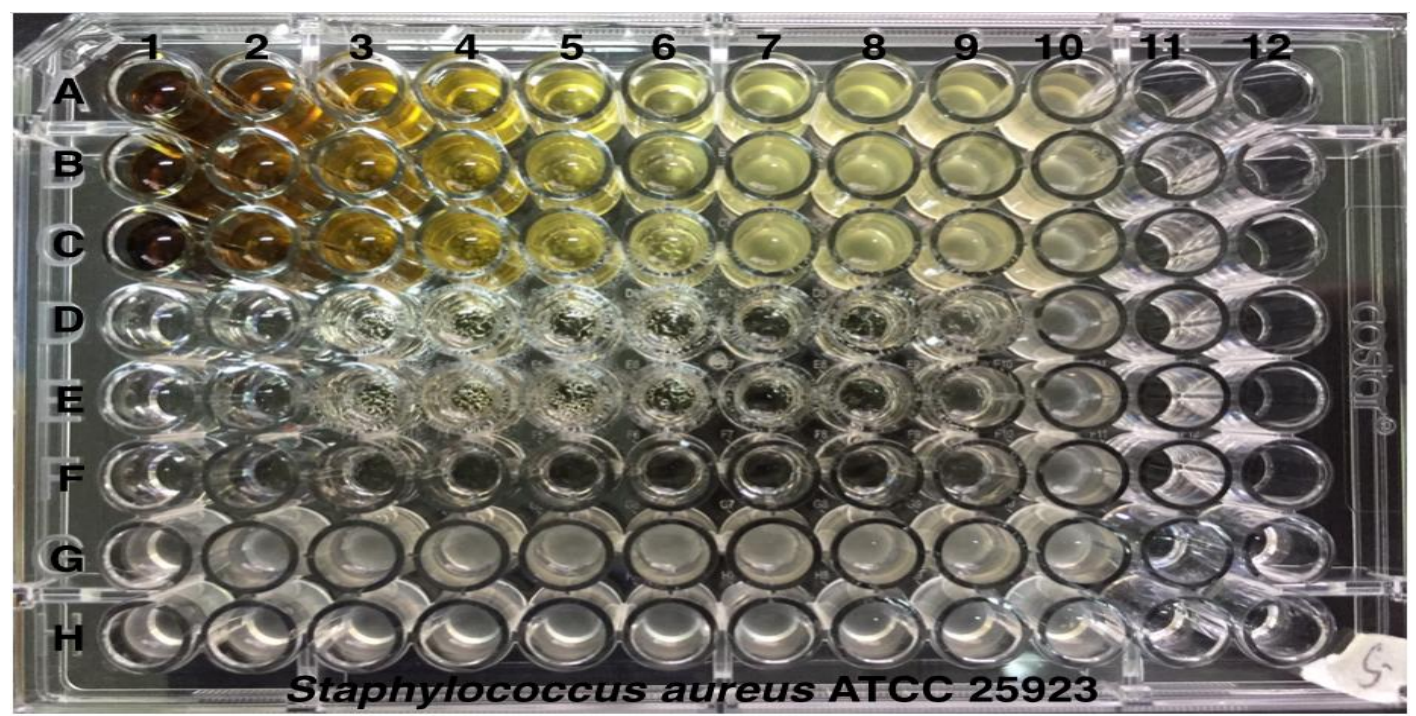

Fig. 5. Growth turbidity of S. aureus ATCC 25923 after 18 hours of incubation with two-fold serially diluted plant extract (rows A,B,C), two-fold serially diluted Amoxicillin (rows D,E,F) and solvents (rows G,H).

Amoxicillin (Rows D,E,F) concentrations from $\approx 500 \mu \mathrm{g} / \mathrm{mL}$ to $\approx 3.8 \mu \mathrm{g} / \mathrm{mL}$ (Wells 1 to 8 ) also inhibited bacterial growth. The MIC of amoxicillin, $\approx 3.8 \mu \mathrm{g} / \mathrm{mL}$, is an indication of a correctly performed assay. The performance standard for antimicrobial susceptibility testing of the Clinical and Laboratory Standards Institute have required to acquire less than $4 \mu \mathrm{g} / \mathrm{mL}$ as the MIC of amoxicillin against $S$. aureus ATCC 25923 to consider the test as valid. In this experiment, the MIC was less than $4 \mu \mathrm{g} / \mathrm{mL}$ indicating the acceptability of the MIC of the plant extract. Bacteria with solvents in Rows $\mathrm{G}$ and $\mathrm{H}$ converted resazurin to a pink resorufin suggesting the presence of viable cells but not in Wells 11 and 12 which contain no viable cells in the sterile Mueller-Hinton Broth.

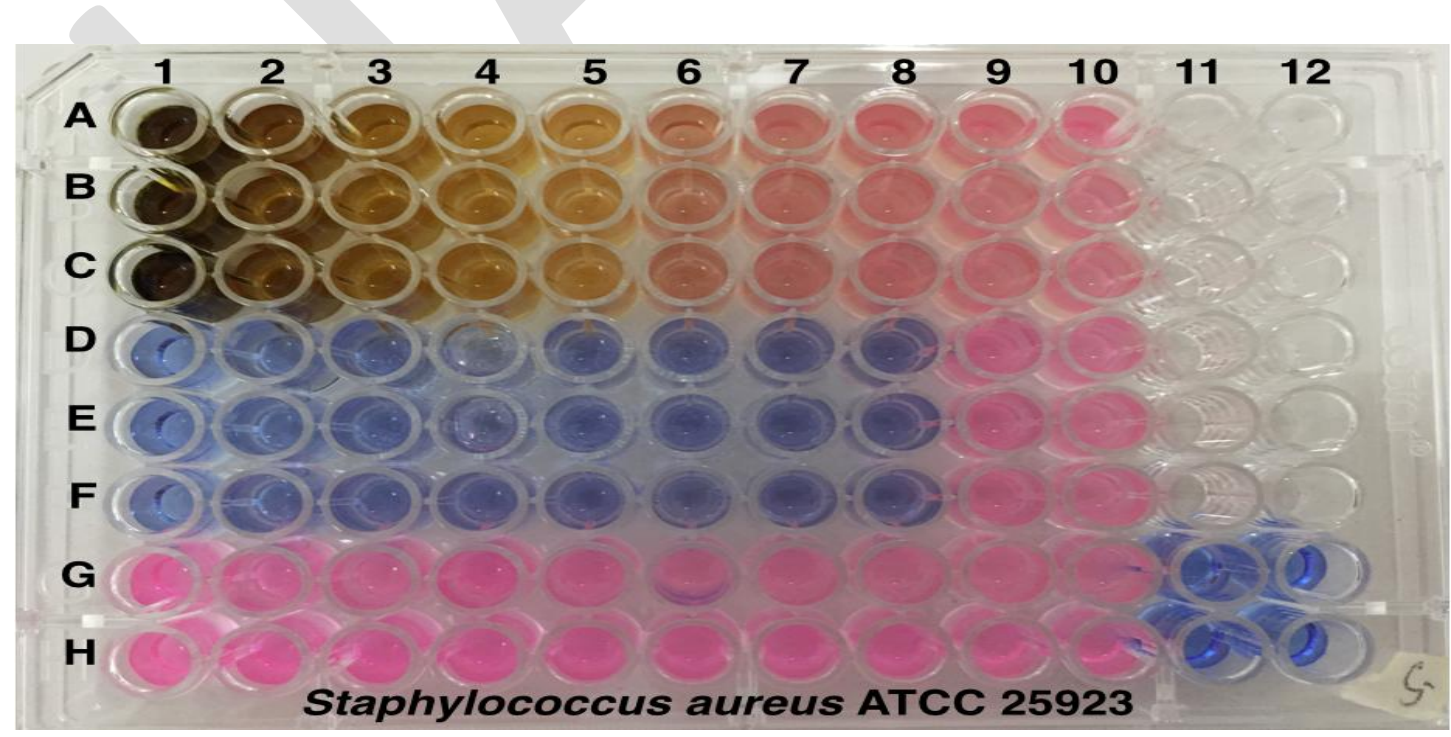

Fig. 6. Viable cells of $S$. aureus ATCC 25923 treated with plant extract and amoxicillin after 18 hours of incubation, with resazurin added to each well and incubated for another 6 hours 
The antibacterial activity of $L$. amara leaf extract, from $6 \mathrm{mg} / \mathrm{mL}$ to $100 \mathrm{mg} / \mathrm{mL}$ concentration against $E$. coli ATCC 25922 and $S$. aureus ATCC 25923 may be due to its bioactive components such as quinoline alkaloid lunacridine [3]. Quinoline alkaloids from L. amara can inhibit Mycobacterium tuberculosis $\mathrm{H} 37 \mathrm{Rv}$ [22, 23]. Moreover, one of quinoline alkaloids, namely, lunacridine was reported as DNA topoisomerase II inhibitor compound [3]. The type of this mechanism leads to antimicrobial activity of the plant based on the inhibition of cell proliferation [24].

\section{Clastogenic and anti-clastogenic activity of Lunasia amara, Blanco}

Micronucleus test was used in the study for assessing chromosome damage because it enables both chromosome loss and chromosome breakage to be measured reliably. The assay detects damage to the chromosome or the mitotic apparatus of immature [14].

Micronuclei are acentric chromosomal fragments or whole chromosomes left behind during mitotic cellular division, appearing in the cytoplasm of interphase cells as small additional nuclei. The detection of micronuclei provides a readily measurable index of chromosome breakage and loss [25]. Decrease in the percentage of polychromatic erythrocytes (PCEs) and increase in percentage of micronucleated polychromatic erythrocytes (MPCEs) are indicators of the chromosomal aberrations and these damages implicate as the major cause for the appearance of nuclei at the last stage of mitosis and as an indicator of genotoxic insult to the nuclei $[26,1]$.

To be considered genotoxic, the MPCEs (Fig. 8) produced by the test samples must be twice or more than twice the negative control. To be considered anti-genotoxic, the MPCEs produced by the test samples in combination with a proven mutagen must be lower when compared with the mutagen alone [14].

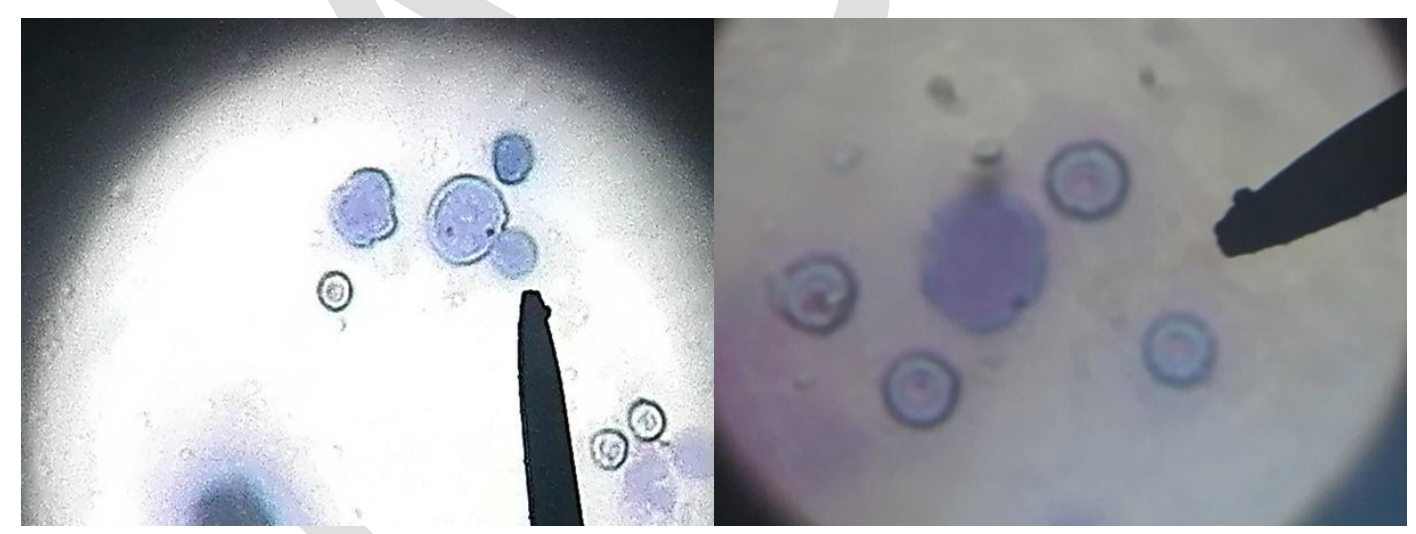

Fig. 7 Micronucleated polychromatic erythrocytes (MPCEs) in the bone marrow cells of Mus musculus, L.

Clastogenic/chromosome-breaking activity of L amara in the bone marrow cells of white mice. Table 1 presents the mean number of micronucleated polychromatic erythrocytes in the bone marrow cells of white mice (M. musculus) produced by L. amara leaf extracts at $200 \mathrm{mg} / \mathrm{mL}$ (T1) and $20 \mathrm{mg} / \mathrm{mL}$ concentrations (T2), respectively, distilled water (negative control, T-) Mitomycin C (positive control, $\mathrm{T}+$ ).

Statistical analysis revealed that results of the study were significant at 5\% level. Analysis of the means revealed no significant difference in the mean number of MPCEs in the bone marrow cells of M. musculus produced by $L$. amara leaf extracts at $200 \mathrm{mg} / \mathrm{mL}$ (T1) and $20 \mathrm{mg} / \mathrm{mL}$ 
concentrations (T2) and the negative control ( T--distilled water). Mitomycin C (T+), however, showed significant difference when compared with the other treatments. It was also found out that Mitomycin's value was twice or more than twice the negative control.

The result showing no significant difference on the MPCEs produced between $L$. amara leaf extracts at $200 \mathrm{mg} / \mathrm{L}$ and $20 \mathrm{mg} / \mathrm{L}$ concentrations and the negative control (distilled water) implies that no chromosome breaking effects were exhibited by the leaf extracts. Even if $L$. amara leaf extracts at $200 \mathrm{mg} / \mathrm{mL}$ (T1) had produced considerable number of MPCEs, the value obtained is below the standard that is twice or more than twice the negative control. This shows that even at high concentration, more than 10x the concentration of the extract with anti-oxidant and antibacterial activities, it did not alter the chromosome of the bone marrow cells of M. musculus, hence, non-clastogenic. The higher number of MPCEs produced by $L$. amara leaf extracts at $200 \mathrm{mg} / \mathrm{mL}$ (T1) as compared with leaf extract of L. amara at $20 \mathrm{mg} / \mathrm{mL}$ (T2), however, implies that at higher concentration, it may pose toxicity to M. musculus but not significant enough to cause damage in the DNA. It is possible that the alkaloids present on it may had become toxic at higher concentration [6].

Genotoxin, such as Mitomycin C on the other hand, induced appreciable formation of MPCEs. Mitomycin $\mathrm{C}$ is an antibiotic which acts as a double-stranded DNA alkylating agent. It covalently crosslinks DNA, inhibiting DNA synthesis and cell proliferation. It acts by way of reductive activation either through low $\mathrm{pH}$ or $\mathrm{NAD}(\mathrm{P}) \mathrm{H}$ :quinone oxidoreductase (DT-diaphorase) or $\mathrm{NADH}$ cytochrome c reductase [27].

Table 1. Clastogenic/Chromosome breaking effects of $L$. amara leaf extracts

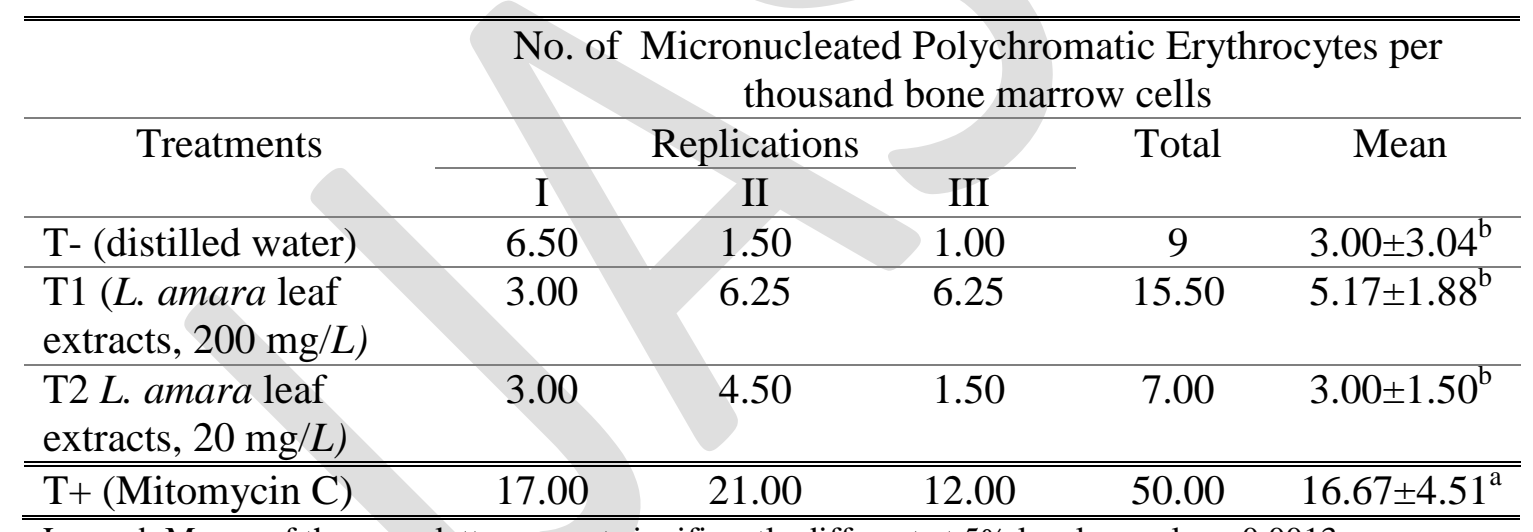

Legend: Means of the same letter are not significantly different at $5 \%$ level , $\mathrm{p}$ value $=0.0013$

Anti-clastogenic/chromosome-breaking activity of L. amara against Mitomycin $C$ in the bone marrow cells of white mice. As shown in Table 2, the chromosome-breaking effect of Mitomycin $\mathrm{C}$ was reduced by $L$. amara leaf extracts. Statistical analysis revealed that results were significant at 5\% level. Tukey's Multiple Range Test revealed significant difference in the mean number of MPCEs produced by T3 (L. amara leaf extracts, $200 \mathrm{mg} / L+$ Mitomycin C) and T4 (L. amara leaf extracts, $20 \mathrm{mg} / L$ L. amara + Mitomycin C) with that of the positive control, T+ (Mitomycin C).

Results showed that the combination of Mitomycin C and L. amara leaf extracts produced lesser number of MPCEs when compared to Mitomycin $\mathrm{C}$ alone. The reduction is significant as shown by the statistical evaluation using ANOVA. The reduction of formation of MPCEs by L. amara leaf extracts indicates that the fragmentation of the chromatin material by Mitomycin $\mathrm{C}$ is reduced. Since Mitomycin C is metabolized to alkylating agent of DNA, there is a possibility that $L$. amara 
leaf extracts inhibits its metabolism to species reactive with DNA, thus, reducing the chromosomebreaking effects of Mitomycin $\mathrm{C}$, hence, anti-clastogenic/chromosome-breaking.

Since L. amara was found to have anti-oxidant activity by the DPPH free-radical scavenging assay, thus it has also the ability to reduce the clastogenic activity of any mutagen because of the flavonoids present on it . In addition, another active components of L. amara are quinoline alkaloid lunacridine [3] and steroids [4].

Flavonoid is an anti-oxidant, able to reduce free radical formation and to scavenge free radicals [20, 21] Quinoline alkaloid lunacridine was reported as DNA topoisomerase II inhibitor compound [3] and steroids are precursors of vitamin $\mathrm{D}$ which can shield the interaction of mutagens with base pairs of DNA [11] with the developing blood cells preventing the formation of MPCEs. It is also possible that substances of undetermined structures are responsible for the reduction of genotoxic/chromosome breaking effects of Mitomycin C.

Table 2. Anti-clastogenic/ effects of L. amara leaf extracts against Mitomycin C

\begin{tabular}{|c|c|c|c|c|c|}
\hline \multirow{3}{*}{ Treatments } & \multicolumn{5}{|c|}{$\begin{array}{l}\text { No. of Micronucleated Polychromatic Erythrocytes per } \\
\text { thousand bone marrow cells }\end{array}$} \\
\hline & & eplicati & $>$ & Total & Mean \\
\hline & I & II & III & & \\
\hline T- (distilled water) & 6.50 & 1.50 & 1.00 & 9.00 & $\begin{array}{l}3.00 \pm \\
3.04^{\mathrm{b}}\end{array}$ \\
\hline $\begin{array}{l}\mathrm{T} 3(\text { L. amara leaf } \\
\text { extracts , } 200 \mathrm{mg} / L+ \\
\text { Mitomycin C) }\end{array}$ & 6.00 & 4.50 & 7.00 & 17.50 & $\begin{array}{l}5.83 \pm \\
1.26^{b}\end{array}$ \\
\hline $\begin{array}{l}\mathrm{T} 4(\text { L. amara leaf } \\
\text { extracts, } 20 \mathrm{mg} / L+ \\
\text { Mitomycin C) }\end{array}$ & 2.00 & 2.50 & 5.00 & 9.50 & $\begin{array}{l}3.17 \pm \\
1.61^{b}\end{array}$ \\
\hline $\mathrm{T}+($ Mitomycin $\mathrm{C})$ & 17.00 & 21.00 & 12.00 & 50.00 & $\begin{array}{r}16.67 \pm \\
4.51^{\mathrm{a}}\end{array}$ \\
\hline
\end{tabular}

$=$ Legend: Means of the same letter are not significantly different at $5 \%$ level, $\mathrm{p}$ value- 0.0012

\section{CONCLUSION}

Lunasia amara, Blanco leaf extract (at $6 \mathrm{mg} / \mathrm{mL}$ concentration) possesses the potential to cause free-radical scavenging/ anti-oxidant activity and caused significant inhibition on the growth of S. aureus, ATCC 25923) and E. coli ATCC 25922 It did not cause chromosome-breakage on white mice (at $20 \mathrm{mg} / \mathrm{mL}$ and $200 \mathrm{mg} / \mathrm{mL}$ concentrations), however, possesses the ability to reduce the chromosome breakage of Mitomycin $\mathrm{C}$ on white mice, hence, anti-clastogenic.

Result of the study can help different agencies in the discovery of potential medicinal values of different plants, particularly the indigenous plants in the Philippines. It can provide cheaper naturebased alternative medicine to the public in the midst of high-priced medicine produced by pharmaceutical companies. Through this study, the importance of plant biodiversity in Mt. Arayat, Pampanga, Philippines will also be highlighted as a source of raw materials (i.e., plants) for medicinal purposes. 


\section{REFERENCES}

[1] E. V. Totaan. Phytochemistry, genotoxicity and anti-genotoxicity screening of Calamus spinifolius, Becc. International Journal of Sciences: Basic and Applied Research, vol 30(3), pp. 102-112, 2016.

[2] A.P.G. Macabeo and A. M. Aguinaldo. Chemical and phytomedicinal investigations in Lunasia amara. Pharmacognosy Reviews [Phcog Rev.], vol. 2(4), pp. 317-325, 2008.

[3] T.A. Prescott, R. Kiapranis and S.K. Maciver. Lunacridine from Lunasia amara is a DNA intercalating topoisomerase II inhibitor. Journal of ethnopharmacology, vol. 109(2), pp. 289294, 2007.

[4] R.M. Rojales and E. V. Totaan. Phytochemical, Anti-fungal and Teratogenic Evaluations of Lunas Plant (Lunasia amara), 2015.

[5] A. Crozier, M.N. Clifford and H. Ashihara. Plant Secondary Metabolites: Occurrence, Structure and Role in the Human Diet. Blackwell Publishing, 2006.

[6] T.S. Agostini-Costa, R.F. Vieira, H.R. Bizzo, D. Silveria, and M.A. Gimenes. Secondary Metabolites, Chromatography and its Applications, 2012.

[7] A.M. Aguinaldo, V.M Dalangin-Mallari, A. P. Macabeo, L.T. Byrne, and A.F. Yamauchi. Quinoline alkaloids from Lunasia amara inhibits Mycobacterium tuberculosis $\mathrm{H} 37 \mathrm{Rv}$ in vitro. Int J Anti-microb Agents, vol. 29(6), pp. 744-746, 2007.

[8] A.D. Agrawal. Pharmacological Activities of Flavonoids: A Review. International Journal of Pharmaceutical Sciences and Nanotechnology, vol. 4(2), pp. 1394-1398, 2011.

[9] S. Bhattacharya. Natural Antimutagens: A Review. Research Journal of Medicinal Plant, vol. 5(2), pp. 116-126, 2011.

[10] B.Q. Guevarra (ed). Phytochemical Screening: Phytochemical and Biological. UST. Manila, Philippines, 2005.

[11] C.Y.L. Sylianco. Genetic Toxicology, Academy, Taguig, National Academy of Science and Technology, 1990.

[12] P. Molyneux. The use of the stable free radical diphenylpicryl-hydrazyl (DPPH) for estimating antioxidant activity. Songklanakarin J. Sci. Technol., vol. 26, pp. 211-219, 2004.

[13] S. Sarker, L. Nahar and Y. Kumarasamy Microtitre plate-based antibacterial assay incorporating resazurin as an indicator of cell growth, and its application in the in vitro antibacterial screening of phytochemicals. Methods vol. 42, pp. 321-324, 2007.

[14] W. Schmid, W. (1975). The micronucleus test. Mutation Research/Environmental Mutagenesis and Related Subjects, vol. 31(1), pp. 9-15, 1975.

[15] G. -C. Yen, P. -D. Duh and H. -L. Tsai, Food Chem., vol. 79, pp. 307-313. 2002.

[16] B. Badhani, N. Sharma and R. Kakkas. Gallic acid: a versatile antioxidant with promising therapeutic and industrial applications. RSC Advances, 2015. 
[17] S.S. Ali, N. Kasoju, A. Luthra, A. Singh, H. Sharanabasava, A. Sahu and U. Bora. Indian medicinal herbs as source of antioxidants. Food Res. Int., vol. 41, pp. 1-15, 2008.

[18] Balanguit, B.J. and R. Fuentes. Preliminary phytochemical screening and antioxidant activity of some brown algae Sargassum species from Lawaan, Eastern Samar. Journal of Nature Studies, vol. 1491, pp. 12-21, 2015.

[19] J.C. Gutteridge. Lipid peroxidation and antioxidants as biomarkers of tissue damage. Clinical Chemistry, vol. 41(12), pp. 1819-1828, 1995.

[20] P.G. Pietta. Flavonoids as antioxidants. J.Nat. Prod., vol. 3(7), pp. 1035-1042, 2010.

[21] E. Yordi, E. Peres, M. Matos and E. Villares. Structural alerts for predicting clastogenic activity of pro-oxidant flavonoid compounds: quantitative structure-activity relationship study. Journal of Biomolecular Screening, vol.17(2), pp. 216-224, 2012.

[22] A.M. Aguinaldo, V.M. Dalangin-Mallari, A.P. Macabeo, L.T. Byrne, F. Abe, T. Yamauchi, et al. Quinoline alkaloids from Lunasia amara inhibit Mycobacterium tuberculosis H37Rv in vitro, Int J Antimicrob Agents, vol. 29 (6)), pp. 744-746, 2007.

[23] M.S. Zubair, S. Anam and S. Lallo. Cytotoxic activity and phytochemical standardization of Lunasia amara Blanco wood extract. Asian Pac J Trop Biomed vol. 6(11), pp. 962-966, 2016.

[24] M.M. Cowan, M.M. Plant products as antimicrobial agents. Clin Microbiol Rev., vol. 12, pp. $564-82,1999$.

[25] M.S. Khan et. al. Genotoxicity: in vivo cytogenetic assay. International Journal of Pharmamedix India, vol. II, pp. 792-803, 2014.

[26] A.E. Salam, E.H.A. Hussein, H.A. El-Hruby, W.A. Anwar and S.A. Mansong. The mutagenicity of gramoxome (Paraquate) on different eukaryotic systems," Mutat. Res, vol. 319, pp. 89-101, 1993.

[27] J. Verweij and H. Pinedo. Mitomycin C: mechanism of action, usefulness and limitations. Anti-Cancer Drugs, vol. 1, pp. 5-13, 1990. 